\title{
Population parameters of the Pacific flagfin mojarra Eucinostomus currani (Perciformes: Gerreidae) captured by shrimp trawling fishery in the Gulf of California
}

\author{
Juana López-Martínez ${ }^{1 *}$, Jesús Rodríguez-Romero ${ }^{2}$, Norma Y. Hernández-Saavedra² \\ \& Eloisa Herrera-Valdivia ${ }^{1}$ \\ 1. Centro de Investigaciones Biológicas del Noroeste, Unidad Sonora, Km. 2.35 carretera a Las Tinajas S/N Las Tinajas, \\ Guaymas, Sonora 85465, Mexico; jlopez04@cibnor.mx, eloisa04@cibnor.mx \\ 2. Centro de Investigaciones Biológicas del Noroeste, Mar Bermejo 195 Col. Playa Palo de Santa Rita, La Paz, B.C.S. \\ 23090, Mexico; jrodri04@cibnor.mx,nhernan04@cibnor.mx \\ * Correspondencia
}

Received 24-V-2010. Corrected 01-XII-2010. Accepted 17-I-2011.

\begin{abstract}
Shrimp trawling fishery in the Gulf of California captures a wide variety of non-target species of fish, crustaceans, and mollusks that are relatively unknown. The Pacific flagfin mojarra Eucinostomus currani is a frequently found species in these catches, nevertheless, nothing is currently known about its population dynamics. To contribute to the knowledge on this fish species, we studied the size structure, growth, mortality, and the recruitment pattern during the 2004-2005 seasons. A total of 6078 mojarra were captured from 350 samples, with minimum and maximum lengths of $4.5 \mathrm{~cm}$ and a maximum of $21.0 \mathrm{~cm}$. The average total length of the four major cohorts was $11.4,13.7,15.6$ and $18.0 \mathrm{~cm}$, corresponding to ages $0.9,1.2,1.6$ and 2.2 years, respectively, being the most abundant the 1.2 year-old group. The instant growth coefficient indicated moderate growth rates $\left(\mathrm{K}_{\mathrm{S}}=0.81 /\right.$ year, $\mathrm{K}_{\mathrm{E}}=0.85 /$ year $)$, corresponding to individuals living between 3.5 to 3.7 years. The estimated asymptotic lengths was $\mathrm{L}_{\infty}=21.8 \mathrm{~cm}$. In general, the population could be considered healthy: natural mortality ( $M=1.53$ /year); total mortality $(\mathrm{Z}=2.73$ /year); condition factor $(\mathrm{K}=0.01072)$; fishery mortality $(\mathrm{F}=1.2 /$ year) and exploitation rate ( $\mathrm{E}=0.43 /$ year). The maximum reproduction period almost coincided with the closed season for shrimp fishing (March to August), thus we concluded that survival of the species is ensured because reproduction is indirectly protected. Rev. Biol. Trop. 59 (2): 887-897. Epub 2011 June 01.
\end{abstract}

Key words: Pacific flagfin mojarra, Eucinostomus currani, Gulf of California, shrimp bycath.

The shrimp trawling is one of the most important economic activities in the Gulf of California. During trawling activities many fish, crustacean and mollusk species are caught as bycatch. Based on preliminary surveys, has been demonstrated that over $98 \%$ of fish and invertebrate by-catch are obtained during this region shrimp trawling (Rodríguez et al. 2009). Most of the bycatch is thrown back into the sea, because it has no commercial value or the organisms have too small sizes (Herrera 2004).

The Gerreidae family has a wide distribution in tropical and subtropical latitudes and constitutes an abundant resource of commercial importance in Mexico coastal lagoons (Grijalva-Chon et al. 1996).

Eucinostomus currani Zahuranec in Yáñez-Arancibia, 1980 is a coastal species found from California and the Gulf of California to Northern Peru, the Galapagos Islands and the Cocos Island. They congregate in small shoals. Larvae are pelagic and the juveniles are commonly found in protected environments, from as estuaries, mangroves, tidal channels, rivers deltas to $20 \mathrm{~km}$ offshore, and hypersaline mangroves. Adults often occur in deeper waters 
(0 to $30 \mathrm{~m}$ ). It is an omnivorous fish that feeds on plants, organic matter, micro-invertebrates, mollusks and detritus (Bussing 1998). A maximum size of $24 \mathrm{~cm}$ has been observed (Franke \& Acero 1996); this species has low commercial value and is commonly used as bait.

Although E. currani is one of the most frequent species in the shrimp bycatch, no study has addressed the effect of the incidental capture on its population dynamics, because there is very little knowledge about the species on wild or captivity conditions. Previously, it was reported that E.currani is a slow growing species, since in captivity the specimen reached $0.24 \mathrm{~g}$ in one day, making it unattractive for commercial purposes (Rubio et al. 2004). The main objective of this study was to estimate the population parameters of the Pacific flagfin mojarra obtained from the shrimp trawl catches in the Gulf of California.

\section{MATERIALS AND METHODS}

Study area: In the Gulf of California, the trawling shrimp takes place on the continental shelf at depths between nine to $90 \mathrm{~m}$. During the shrimp season (August-March 2004-2005), 10 observers on board the Sonora shrimp fleet homeport, operating on the Sonora, Sinaloa and Nayarit platform (21 1 ' $37^{\prime \prime}-31^{\circ} 24^{\prime} 35^{\prime \prime}$ N-105'16'06"-114²2'51" W) (Fig. 1). All tows were made at night. In each throw, the observers took randomly $20 \mathrm{~kg}$ samples of the total capture. The samples were stored in plastic bags at $-20^{\circ} \mathrm{C}$ and labeled with the data collection site. The samples were processed at the Fisheries and Ichthyology Laboratory CIBNOR.

Morphometric measurements: In the laboratory, samples were thawed and separated by taxonomic groups. Identification to species level was done using the taxonomic keys of Bussing (1995), Jordan \& Everman (1896), Allen \& Robertson (1994) and Nelson et al. (2004, 2006) taxonomic keys. The diacritical characteristics of E. currani used for identification were: tri-banded dorsal fin (grey at the base, silver-light in the midsection, and deep black at the tip), no color pattern on either side

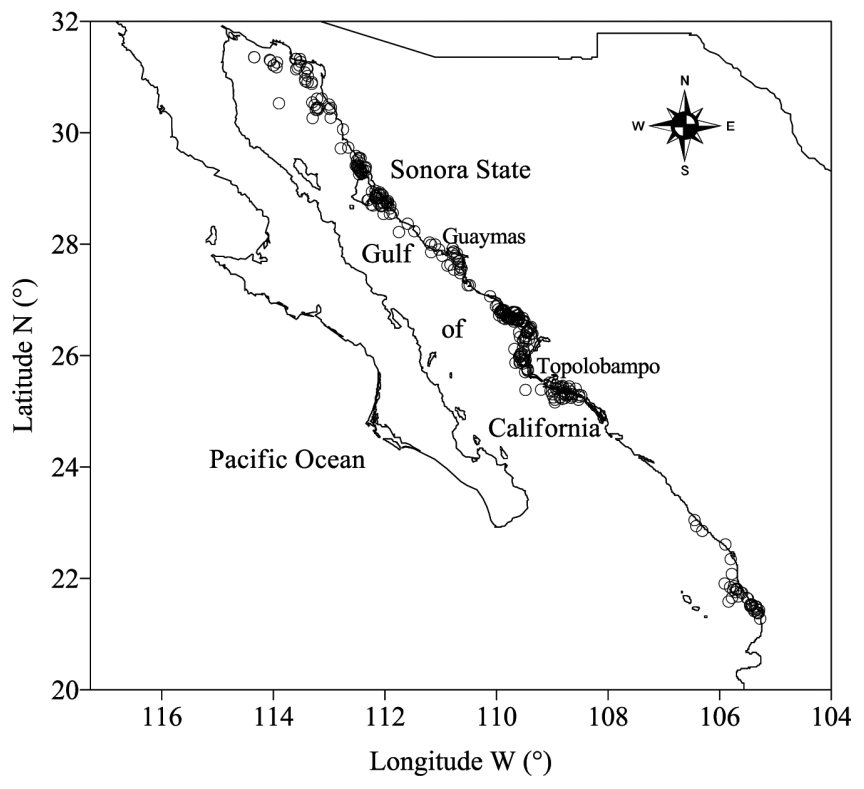

Fig. 1. Sampling areas along the coast of Sonora, Sinaloa and Nayarit, México.

Fig. 1. Áreas de muestreo a lo largo de la costa de Sonora, Sinaloa y Nayarit, México. 
of the body. Some young specimens have dark spots (Yáñez-Arancibia 1980).

Morphometric measurements of each organism included total length (from the mouth to the end of the caudal fin), standard length (from the mouth to the end of the caudal peduncle), weight, sex and sexual maturity. To determine sexual maturity, the reference scale of Nikolsky (1963) was used (gonad morphochromatic characterization), which is based on color and gonad texture, as well as its space in the abdominal cavity.

The parameters $a$ and $b$ of the length-weight relationship $\left(\mathrm{W}=\mathrm{aL}^{\mathrm{b}}\right)$, where $\mathrm{W}$ is weight $(\mathrm{g})$ and $\mathrm{L}$ is length $(\mathrm{cm})$, were determined by means of a potential regression. The $b$ value of the weight-length relationship was used for the condition factor calculation. Individual values of the condition factor were obtained through the formula $\mathrm{K}=\mathrm{W} / \mathrm{TL}^{\mathrm{b}}$, where $\mathrm{W}$ is weight and TL is total length. The monthly means were calculated from individual values.

In order to obtain size frequencies for each two-week period, data were grouped by intervals of five total length subgroups. To determine number of the cohorts in a capture, Bhattacharya proposed a method (Pauly \& Caddy 1985), assuming a normal distribution around the average size of each cohort.

By using the mean and standard deviation of each cohort like the initial data, NORMSEP analysis (maximum verisimilitude) was performed (Sparre \& Venema 1995). Growth was calculated from the size frequency distribution analysis assuming that $E$. currani follows a von Bertalanffy kinetics model (Pauly et al. 1984, Brey \& Pauly 1986). Besides, ELEFAN I was used to estimate growth parameters (Pauly \& David 1981, Pauly 1987). This method was selected because it incorporates seasonal growth, which is characteristic of the fauna in the transition from tropical to temperate areas, such as the one from the Gulf of California (Pauly et al. 1984, García 1988). The seasonalgrowth model has the following form:

$$
L_{t}=L_{\infty}\left(1-e^{-\left[K\left(t-t_{0}\right)+C(K / 2 \pi) \sin 2 \pi\left(t-t_{s}\right)\right]}\right)
$$

where $L_{t}$ is the length at time t, $L_{\infty}$ is the asymptotic length, $K$ is the instant growth coefficient (per year), $t_{0}$ is the hypothetical time at which the length of the organism is zero, $t_{s}$ is the beginning of sinusoidal growth oscillation with respect to $\mathrm{t}=0$, and $C$ is the intensity of the oscillation of growth.

To start the estimations, seed values of $L_{\infty}$ were calculated by the methods of Powell (1979) and Wetherall et al. (1987). The K value was calculated by the Shepherd's length composition analysis (NSLCA) (Shepherd 1987, Pauly \& Arreguín 1995), while estimates of the third parameter ( $t 0)$ were performed with the empirical equation proposed by Pauly et al. (1984).

Natural mortality (M) was determined by the empirical equation proposed by Pauly (1980),

$\ln M_{i}=-0.0152-0.279 * \ln L_{\propto_{i}}+0.6543 * \ln K_{i}+0.463 * \ln T_{i}$

where $\mathrm{T}$ is the habitat's average annual sea surface temperature, and by the $M=1.5 \times \mathrm{K}$ equation (Jensen 1996), where $\mathrm{K}$ is the instant growth coefficient.

Total mortality and capture probability (selectivity) were estimated with the lengthconverted catch curve method (Pauly et al. 1984). Fishing mortality was estimated from the difference of $\mathrm{Z}=\mathrm{F}+\mathrm{M}$, and the exploitation rate $\mathrm{E}=\mathrm{F} / \mathrm{Z}$, where values over 0.5 reflect overexploited populations, and values under 0.5 denote a sub-exploited ones (Gulland \& Rosemberg 1992).

Because the information on E. currani only includes the months of the fishing season (September to March), the pattern of reproductive recruitment was used as an alternative method to determine the probable birth date of the organisms caught, by the method ELEFAN II (Pauly 1980, 1987), that analyses the size structure of catches once the selection bias is corrected. The results generated by this model should be treated as approximations, since statements on the annual reproductive pulses number and on their relative strength, is based 
on the assumptions that fish in the sample grow as described by a single set of growth parameters, and that one month a year has zero recruitment (Moreau \& Cuende 1991).

Size at first maturity was calculated from the number of mature females at stages III and IV in each size group. The relationship between size and maturity was fitted to a nonlinear estimate, using the least squares procedure. To test the appropriateness of the logistic model, we used the determination coefficient $\left(\mathrm{R}^{2}\right)$. The maturity-length relationship describes a logistic curve (Pauly 1984):

$$
S_{L}=\left(\frac{1}{1+\exp (-r *(X-X 50))}\right)
$$

where $r$ and $X 50$ are sigmoid parameters. The size at first maturity (L50\%) is described as the point that intercepts $50 \%$ of the logistic model. In this case, $\mathrm{L} 50 \%=X_{50}$ (Pauly 1984). As the same, the selectivity-length relationship describes a logistic curve and was fitted to a nonlinear estimate, using the least squares procedure.

\section{RESULTS}

In the samplings, Pacific flagfin mojarra was one of the most common by-catch species $(9 \%)$. In this study were measured 6 078 mojarra from 350 samples collected from August $15^{\text {th }} 2004$ to March $15^{\text {th }} 2005$ (Fig. 2). Their lengths ranged from 4.6 to $21.0 \mathrm{~cm}$. Four cohorts, in terms of mean total length, were $11.4,13.7,15.6$, and $18.0 \mathrm{~cm}$, corresponding to ages $0.9,1.2,1.6$, and 2.2 years were found; the 1.2 year-old group was the most abundant.

Estimates for the weight-length relationship showed that coefficient b was 3.065 (Lo conf. limit=3.021817, Lu conf. limit $=3.040513$; p-level $=0.00$ ) and coefficient was 0.000011 (Lo conf. limit $=0.000011$, Lu conf. limit $=0.000011$; p-Level $=0.00)$ and the correlation coefficient $\mathrm{R}$ was $\mathrm{R}=0.9750$ ( $\mathrm{p}$-level $=0.00$ ). Was found a moderate growth $\left(\mathrm{K}_{\mathrm{S}}=0.81 /\right.$ year, $\mathrm{K}_{\mathrm{E}}=0.85$ / year) corresponds to specimens that were $\sim 3.7$ years old (longevity $=3 / \mathrm{K}$ ) as well as an asymptotic length of $\mathrm{L}_{\infty}=21.8 \mathrm{~cm}\left(\mathrm{~W}_{\infty}=128.1 \mathrm{~g}\right)$ by the
Shepherd and ELEFAN I methods, when $\mathrm{t}_{0}=-$ 0.216 (Table 1). The resulting curve is shown in Fig. 3.

TABLE 1

Eucinostomus currani growth parameters based on bycatch from commercial shrimp trawling in the Gulf of California

CUADRO 1

Parámetros de crecimiento de Eucinostomus currani basado en la fauna de acompañamiento del camarón obtenido por arrastres en el Golfo de California

\begin{tabular}{lccc}
\multicolumn{1}{c}{ Method } & $\mathrm{K} /$ year & $\mathrm{L}_{\infty}($ total, cm) & $\mathrm{T}_{0}$ \\
Powell-Wetherall & & 22.0 & \\
Shepherd & 0.81 & 21.81 & -0.216 \\
ELEFAN I & 0.85 & 21.80 &
\end{tabular}

$\mathrm{K}=$ instant growth coefficient, $\mathrm{L}_{\infty}=$ asymptote length, $\mathrm{T}_{0}=$ time to length equal to zero.

The condition factor average was $\mathrm{K}=0.01072$, and $\mathrm{K}$ index showed the lowest value in February and the highest value in March (this is, at the beginning of the reproductive period) (Fig. 4).

The estimated natural mortality was $\mathrm{M}=1.53 /$ year; total mortality $\mathrm{Z}=2.73 /$ year $(\mathrm{CI}$ 1.9-3.5); fishery mortality $\mathrm{F}=1.2 /$ year, and exploitation rate is $\mathrm{E}=0.43$ /year. Mortality values for fishery and exploitation rates suggest a healthy population. Although samples were as small as $4.6 \mathrm{~cm}$, first-capture estimated size was $12.85 \mathrm{~cm}$, with a value of $\mathrm{L}_{50 \%}=12.8 \mathrm{~cm}$ $\left(\mathrm{t}_{50 \%}=10\right.$ months) and $\mathrm{L}_{75 \%}=14.3 \mathrm{~cm}\left(\mathrm{t}_{75 \%}=13.2\right.$ months) and selection rank $\mathrm{R}=30 \mathrm{~mm}$ (Fig. 5). The resultant adjusted equation to the logistic selectivity model is:

$$
P=\frac{1}{1+e^{-0.0731(X-12.85)},}
$$

where $P$ is the probability of capture and $X$ is the total length in $\mathrm{cm}$.

Incorporation of new recruits was observed throughout the year, with two peaks: the first of $30.07 \%$ from March to April and the 
Sep.

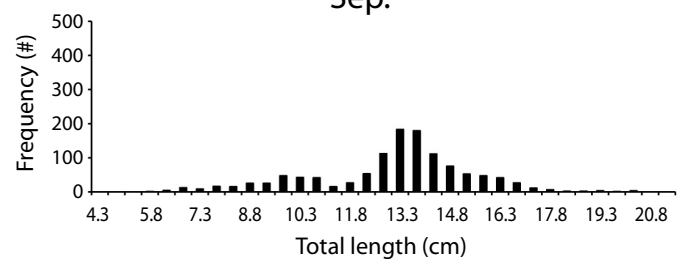

Oct.

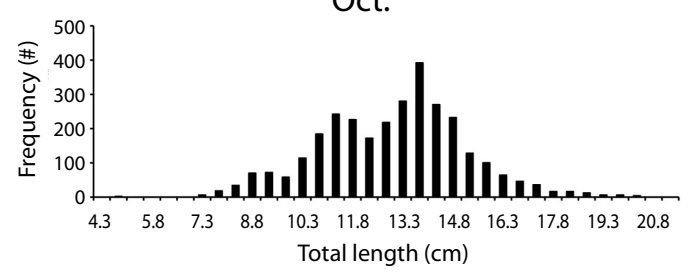

Nov.
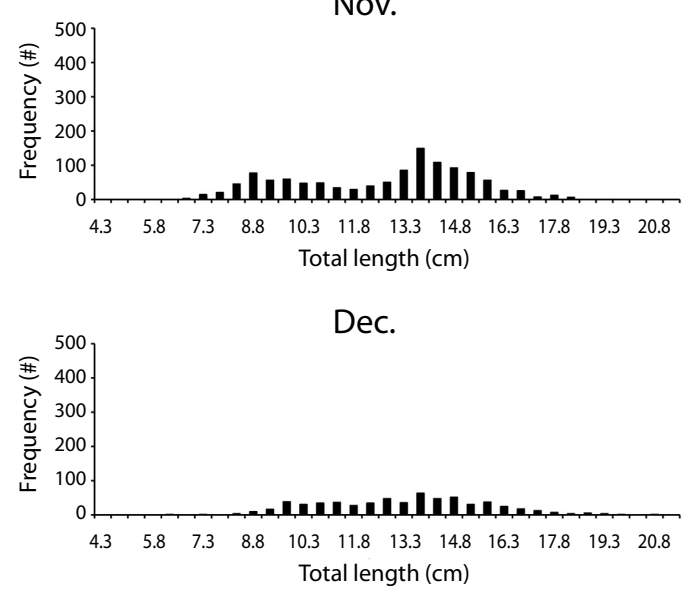

Jan.

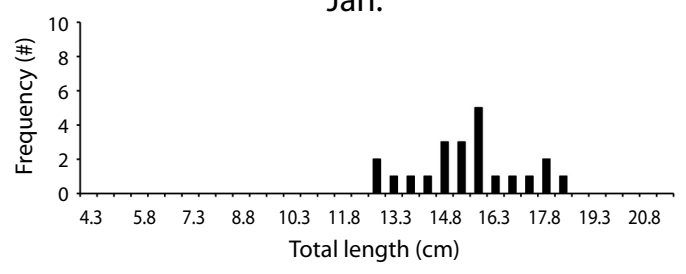

Feb.

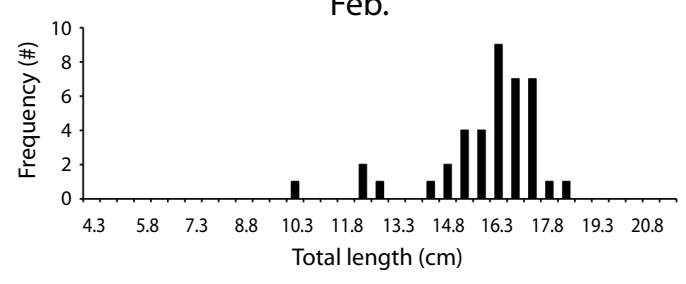

Mar.

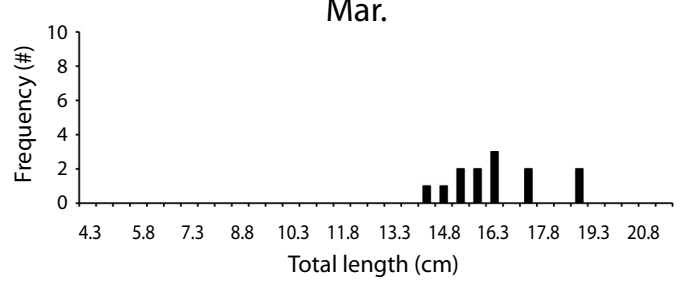

Fig. 2. Size structure of Eucinostomus currani based on by-catch from commercial shrimp trawling during the catch seasons of 2004 and 2005 .

Fig. 2. Estructura de tallas de Eucinostomus currani badasa en muestreos de fauna de acompañamiento del camarón capturado con arrastre en las temporadas de pesca 2004 y 2005.

second of $29.19 \%$ from June through August (Fig. 4). The size at first maturity was estimated at $14.2 \mathrm{~cm}$ of total length, corresponding to an approximate age of 15 months (Fig. 5). The adjusted equation to the logistic model was:

$$
P=\frac{1}{1+e^{-0.1076(X-14.2)}}
$$

\section{DISCUSSION}

The Pacific flagfin mojarra is the most abundant species in shrimp bycatch in the Gulf of California (López-Martínez et al. 2010). It occupies coastal zones from three to $77 \mathrm{~m}$. In the literature, the maximum depth is stated as 60m (Ayala \& Tapia 1990), but our samples extend this range to $77 \mathrm{~m}$. This mojarra is a 


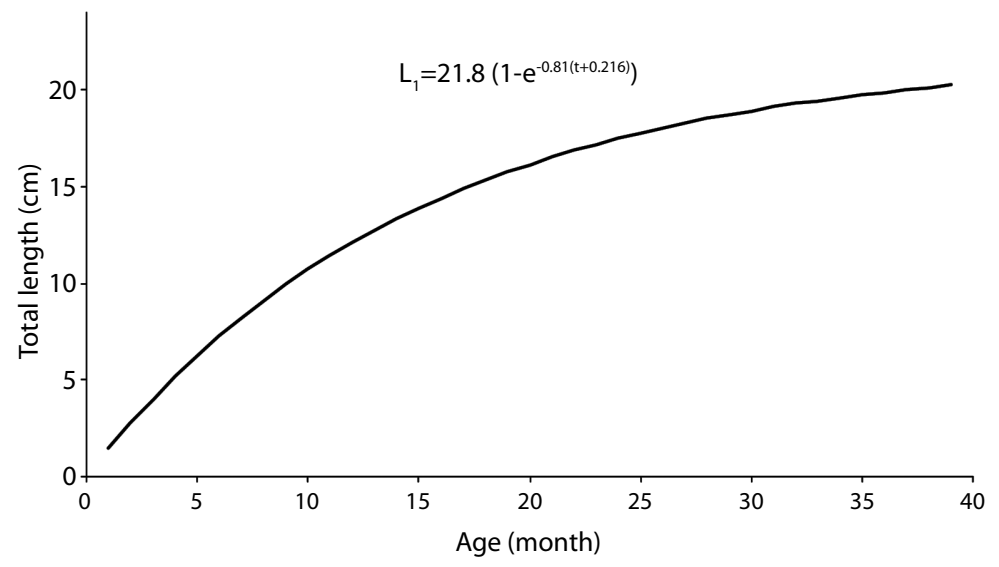

Fig. 3. Growth curve of Eucinostomus currani in the Gulf of California adjusted to the von Bertalanffy model.

Fig. 3. Curva de crecimiento de Eucinostomus currani ajustada al modelo de von Bertalanffy en el Golfo de California.

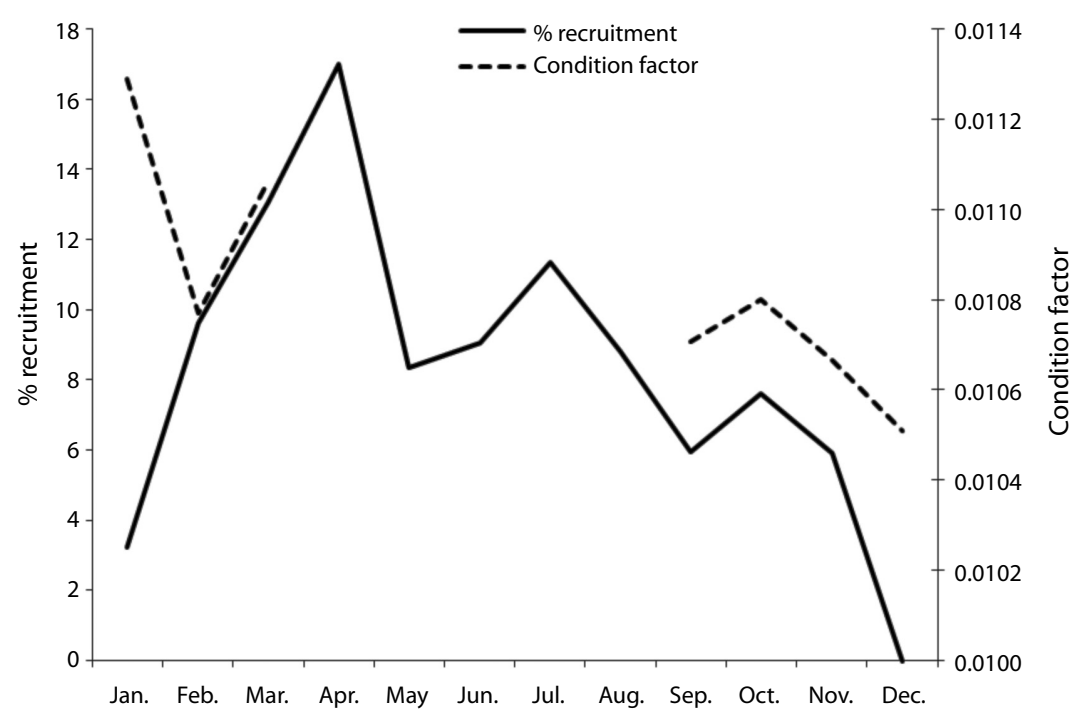

Fig. 4. Monthly recruitment and condition factor of Eucinostomus currani present as by-catch in commercial shrimp trawling in the Gulf of California.

Fig. 4. Reclutamiento y factor de condición mensual de Eucinostomus currani presente en la fauna de acompañamiento de camarón obtenido con redes de arrastre en el Golfo de California. 


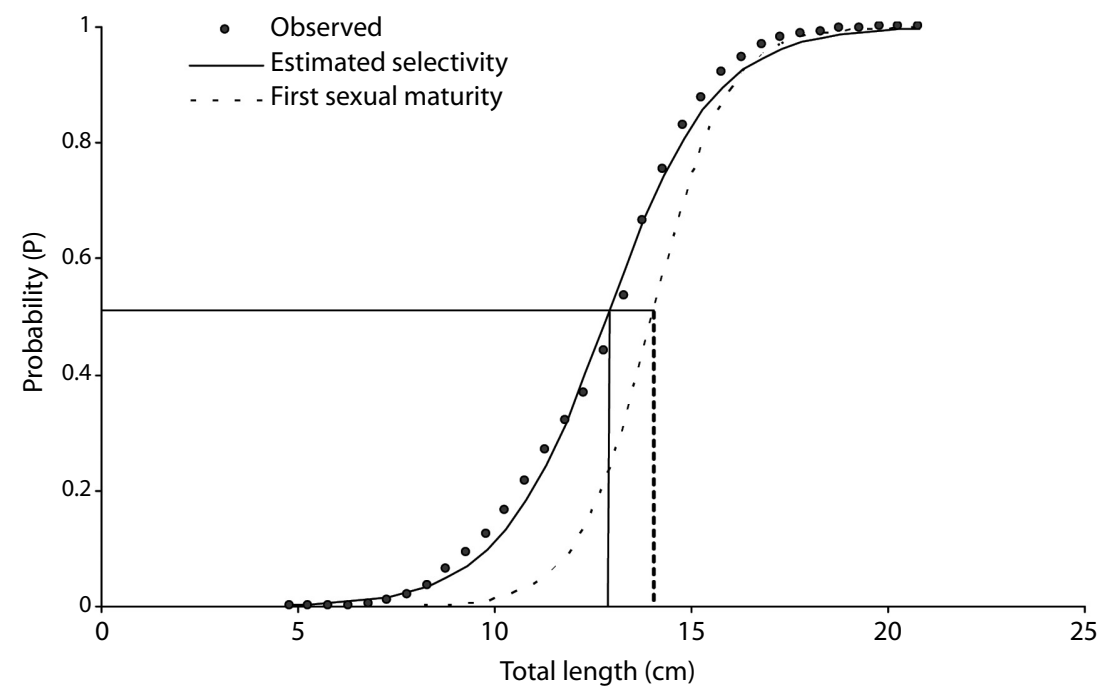

Fig. 5. Selectivity curve and first sexual maturity curve of Eucinostomus currani in the shrimp by-catch in the Gulf of California, adjusted to the logistic model.

Fig. 5. Curvas de selectividad y de primera madurez sexual ajustadas al modelo logístico de Eucinostomus currani en la fauna de acompañamiento del camarón en el Golfo de California.

demersal, freshwater and marine inhabitant in the Mexican Pacific coasts that uses lagoons for protection and feeding in their early developmental stages (Amezcua 1976, Grijalva-Chon et al. 1996). The wider distribution range to depth of the mojarra allow it to remain highly productive, in spite of the high bycatch, and remain competitive in the ecosystem where this species take advantage of habitat and food, as documented for other species from the Southern Baja California peninsula (Rodríguez-Romero et al. 2008). The same as the latitudinal distribution, the distribution in depth of the species, can be limited by thermal barriers and of pressure as well as of type topographical existent in the Gulf of California. The different depth distribution $(5-77 \mathrm{~m})$ of this species, can be due to the existence of big sandy-muddy coastal extensions, that are very productive areas, in the Oriental side of the Gulf of California, and where they support a great diversity of species of fish and other organisms, including this species (Grijalva-Chon et al. 1996, López-Martínez et al. 2010).
The weight-length relationship is according to the value estimate from the same species by Ruíz-Ramirez et al. (1997), González-Acosta et al. (2004), Aguirre et al. (2008) and Velázquez-Velázquez et al. (2009) (Table 2 ) and show an isometric growth.

The Pacific flagfin mojarra has relatively slow growth and a lifespan close to four years. Our results on maximum sizes agree with previous reports (Franke \& Acero 1996, Ruíz-Ramirez et al. 1997). The calculated K value was greater than previously reported values $(\mathrm{K}=0.58)$, corresponding to 4.9 year-old mojarra. This result can be attributed to larger sizes being sampled previously (Ruíz-Ramirez et al. 1997).

The recruitment pattern (the reproductive period) was from March to August and size at first sexual maturity being slightly smaller compared to a previous report on this species in the Gulf of Tehuantepec $(14.5 \mathrm{~cm})$ (RuízRamirez et al. 1997). The condition factor is an index reflecting interactions between biotic and abiotic factors in the physiological 
TABLE 2

Length-weight- relationship of Eucinostomus currani in the Gulf of California from different reports

CUADRO 2

Relación longitud-peso de Eucinostomus currani en el Golfo de California según varios reportes

\begin{tabular}{lcccccc}
\multicolumn{1}{c}{ Author } & $\mathrm{n}$ & $\mathrm{A}$ & $\mathrm{b}$ & $\mathrm{R}$ & p-level & Country \\
Ruíz-Ramírez et al. $(1997)$ & 55 & 0.0268 & 2.7500 & & & Mexico \\
De la Cruz Agüero et al. $(2004)$ & 2709 & 0.0180 & 3.0300 & & Mexico \\
Aguirre et al. (2008) & 174 & 0.000013 & 3.1900 & 0.970 & Mexico \\
Velázquez-Velázquez et al. (2009) & 312 & 0.019 & 3.1700 & 0.98 & Mexico \\
This manuscript & 6078 & 0.000011 & 3.0218 & 0.975 & 0.00 & Mexico
\end{tabular}

condition of fishes. It shows the population's welfare during various stages of the life cycle (Angelescu et al. 1958). In the case of $E$. currani, the condition factor decreases at the start of the spawning period due to very high metabolic rates. Unfortunately, we have data of E. currani only for the months of shrimp fishing (September to March), being impossible to follow the behavior of $\mathrm{K}$ during the period of maximum recruitment. Vazzoler \& Vazzoler (1965), Martins-Juras (1980) and Lizama \& Ambrosio (2002) state that the condition factor does not merely reflect the feeding condition of the adult stage, but includes the state of gonadal development, based on the consumption of fat reserves during the spawning period.

The size structure and the size at first sexual maturity indicated that $58 \%$ of the sample were juveniles ( $<13$ months), this is, sexually immature. In some previous reports, juveniles are commonly found in estuarine regions, mangroves, tidal streams and rivers far from the coast, and the adults occur in deeper waters (De la Cruz-Agüero et al. 1997). This finding is very important, indicating the low selectivity of shrimp nets. E. currani represents an important component of the trophic chain for many marine species in areas of high biological productivity (Ramírez-Luna et al. 2008). By-catch arises because fishing gears have imperfect selection properties, but the problem is made worse by economic pressures resulting from overexploitation. This fact can lead to the decrease in the abundance of both target and non-target species and to inefficient use of resources (Cook 2001).

The consequences of trawling activities on ecosystems have been frequently studied during the past years. Common trends of community responses have been detected, for instance, areas with high disturbance may become more uniform and characterized by fewer and more dominant species (Escolar et al. 2009). In this context, we stress out the important ecological role of the species of bycatch herein analyzed. Reyes-Bonilla et al. (2009) have outlined that in the Gulf of California has diminished the trophic level of the captures, as consequence of the fishing pressure. Arreguín-Sánchez et al. (2002) suggests that fish mortality in the bycatch could have a positive impact on the shrimp stock, due to fact that some species has a diet based in shrimp, diminishing the pressure of the predators to the shrimp. This is the case of the Pacific flagfin mojarra, which bases $45 \%$ of their diet on shrimps (Ramírez-Luna et al. 2008).

The mortality indicators here obtained are relatively low, considering natural and catch conditions, as well as an exploitation rate close to maximum. E. currani is reported as highly "resilient" because its population doubling time is less than 15 months (Froese \& Pauly 2000). Additionally, the recruitment pattern coincides with the peak reproduction period, which closely matches the end of the shrimp fishery season (March through August). We concluded that survival of this mojarra is ensured because 
the reproduction season is indirectly protected. A detailed analysis of the mojarra reproductive biology is recommended.

\section{ACKNOWLEDGMENTS}

Thanks to the participating owners of the shrimp trawlers based in the port of Guaymas, Sonora for facilitating our participation in the shrimp and by-catch surveys. Funds were provided by SAGARPA-CONACYT (SAGARPA grant 2003-C01-089), PRODUCE Sonora grant 26-2009-1356 and CIBNOR (Project EP1.1). Thanks to Ira Foguel English Editor.

\section{RESUMEN}

La pesquería de camarón del Golfo de California captura una amplia variedad de especies incidentales, relativamente no conocidas que incluye peces, crustáceos y moluscos. La mojarra bandera del Pacífico Eucinostomus currani es frecuentemente encontrada en las capturas del camarón y no hay información sobre su dinámica poblacional. La estructura de tallas, crecimiento, mortalidad y patrón de reclutamiento fueron determinados durante la temporada 2004-2005. De manera que se recolectaron 6 078 organismos de esta especie en 350 muestras, las tallas mínima y máxima fueron $4.5 \mathrm{~cm}$ y $21.0 \mathrm{~cm}$. La talla media de las cuatro cohortes presentes fueron 11.4, 13.7, $15.6 \mathrm{y}$ $18.0 \mathrm{~cm}$, correspondiendo a edades de $0.9,1.2,1.6$ y 2.2 años. El coeficiente instantáneo de crecimiento indica un crecimiento moderado $\left(\mathrm{K}_{\mathrm{S}}=0.81 / \mathrm{año}, \mathrm{K}_{\mathrm{E}}=0.85 / \mathrm{año}\right)$, con una longevidad de 3.5 años. La longitud asintótica estimada fue $\mathrm{L}_{\infty}=21.8 \mathrm{~cm}$. En general, la población se mostró saludable, con una mortalidad natural ( $M=1.53 /$ año); factor de condición ( $\mathrm{K}=0.01072)$; mortalidad total $(\mathrm{Z}=2.73$ /año); mortalidad por pesca $(\mathrm{F}=1.2 / \mathrm{año})$ y tasa de explotación $(\mathrm{E}=0.43 / \mathrm{año})$. El periodo de máxima reproducción coincide con la temporada de veda de la pesca de camarón (marzo a agosto). Concluimos que la sobrevivencia de la especie se encuentra indirectamente protegida.

Palabras clave: mojarra bandera del Pacífico, Eucinostomus currani, Golfo de California, fauna acompañante.

\section{REFERENCES}

Aguirre, H., F. Amezcua, J. Madrid-Vera \& C. Soto. 2008. Length-weight relationship for 21 fish species from a coastal lagoon in the southwestern Gulf of California. J. Appl. Ichthyol. 24: 91-92.
Allen, G.R. \& D.R. Robertson. 1994. Fishes of the tropical eastern Pacific. University of Hawaii, Honolulu, Hawaii, USA.

Amezcua, L.F. 1977. Generalidades ictiológicas del sistema lagunar costero de Huizache-Caimanero, Sinaloa, México. An. Inst. Cienc. Mar Limnol, UNAM, México.

Angelescu, V., F.S. Gneri \& A. Nani. 1958. La merluza del mar argentino (biología y taxonomía). Secr. Mar. Serv. Hidrog. Nav. Pub. H., Buenos Aires, Argentina.

Arreguín-Sánchez, F., E. Arcos \& E.A. Chávez. 2002. Flows of biomass and structure in an exploited benthic ecosystem in the gulf of California, Mexico. Ecol. Model. 156: 167-183.

Ayala, G. \& M. Tapia. 1990. Composición y abundancia de la familia Gerreidae en el Golfo de Tehuantepec, con énfasis en las estrategias reproductivas de las especies dominantes. Conabio, México D.F., México.

Brey, T. \& D. Pauly. 1986. Electronic Length Frequency Analysis. A Revised and Expanded User's Guide to ELEFAN 0, 1 and 2. Ber. Inst. Meereskd, University Kiel, Alemania.

Bussing, W.A. 1995. Gerreidae. Mojarras, p. 1114-1128. In: W. Fischer, F. Krupp, W. Schneider, C. Sommer, K.E. Carpenter \& V. Niem (eds.). Guía FAO para identificación de especies para los fines de la pesca. Pacífico Centro-Oriental. FAO, Rome, Italy.

Bussing, W.A. 1998. Peces de las aguas continentales de Costa Rica. Universidad de Costa Rica, San José, Costa Rica.

Cook, R. 2001. The magnitude and impact of by-catch mortality by fishing gear, p. 96-98. In FAO (ed.). Report of Reykiavik Conference on responsable fisheries in the marine ecosystem. Reykiavik, Iceland 1-4 october. FAO Fisheries Report 658, Rome, Italy.

De la Cruz-Agüero, J., M. Arellano-Martínez, V.M. CotaGómez \& G. de la Cruz-Agüero. 1997. Catálogo de los peces marinos de Baja California Sur. IPNCICIMAR, La Paz, Baja California, Mexico.

Escolar, M., M. Diez, D. Hernández, Á. Marecos, S. Campodónico \& C. Bremen. 2009. Invertebrate bycatch in Patagonian scallop fishing grounds: a study case with data obtained by the On Board Observers Program. Biol. Mar. Oceanog. 44: 369-377.

Franke, R. \& A. Acero. 1996. Peces óseos comerciales del Parque Gorgona, Pacífico colombiano (Osteichthyes: Muraenesocidae, Hemiramphidae, Belonidae, Scorpaenidae, Triglidae, Malacanthidae, Gerreidae, 
Sparidae, Kyphosidae, Sphyraenidae e Istiophoridae). Rev. Biol. Trop. 44: 763-770.

Froese, R. \& D. Pauly. 2000. FishBase 2000: concepts, design and data sources. ICLARM Contribution, 1594. ICLARM: Los Baños, Laguna, Philippines.

García, S. 1988. Tropical penaeid prawns, p. 219-249. In J.A. Gulland (ed.). Fish populations dynamics. Wiley, New York, USA.

González-Acosta, A.F., G. De La Cruz-Agüero \& J. De La Cruz-Agüero. 2004. Length-weight relationships of fish species caught in a mangrove swamp in the Gulf of California. J. Appl. Ichthyol. 20:154-155.

Grijalva-Chon, M., S. Núñez, R. Quevedo \& L. Castro. 1996. Ictiofauna de la laguna costera La Cruz, Sonora. Cien. Mar. 22: 129-150.

Gulland, J.A. \& A.A. Rosenberg. 1992. Examen de los métodos que se basan en la talla para evaluar las poblaciones de peces. FAO Fish.Tech. doc. 323. FAO, Rome, Italy.

Herrera, E. 2004. Manual para observadores a bordo de la flota comercial temporada de pesca 2004-2005. Laboratory of fisheries, CIBNOR, Guaymas, Sonora, Mexico.

Jensen, A.L. 1996. Beverton and Holt life history invariant result from optimal trade-off of reproduction and survival. Can. J. Fish. Aquat. Sci. 53: 820-822.

Jordan, D.S. \& B. Everman. 1896. Fishes of North and Middle America. B. Am. Mus. Nat. Hist. 47: 1-1240.

Lizama, M.A.P. \& A.M. Ambrósio. 2002. Condition factor in nine species of fish of the Characidae family in the upper Paraná River Floodplain, Brazil. Braz. J. Biol. 62: 113-124.

López-Martínez, J., E. Herrera-Valdivia, J. RodríguezRomero \& S. Hernández-Vázquez. 2010. Composición taxonómica de peces integrantes de la fauna de acompañamiento de la pesca industrial de camarón del Golfo de California, México. Rev. Biol. Trop. 58: 925-942.

Martins-Juras, I.A.G. 1980. Estudo sobre o crescimento de Macrodon ancylodon (Bloch \& Schneider, 1801) capturada nas costas do Rio Grande do Sul (Latitude $\left.29^{\circ} \mathrm{Sa} 32^{\circ} \mathrm{S}\right)$. Master Tesis, University of São Paulo, Instituto Oceanográfico, São Paulo, Brazil.

Moreau, J. \& F.X. Cuende. 1991. On improving the resolution of the recruitment patterns of fishes. ICLARM Fishbyte 9: 45-46.
Nelson, J.S., E.J. Crossman, H. Espinosa, L.T. Findley, C.R. Gilbert , R.N. Lea. \& J.D. Williams. 2004. Common and scientific names of fishes from the United States, Canada, and Mexico. Amer. Fish. Soc. Spec. Pub. 29, Bethesda, Maryland, USA.

Nelson, J.S., H. Espinosa-Pérez, L.T. Findley, C.R. Gilbert, R.N. Lea, N.E. Mandrak \& J.D. Williams. 2006. Corrections to common and scientific names of fishes from the United States, Canada, and Mexico. Fisheries 31: 138-140.

Nikolsky, G. 1963. The ecology of fishes. Academy, New York, USA.

Pauly, D. 1980. On the interrelation between natural mortality, growth parameters and mean environmental temperature in 175 fish stocks. J. Cons CIEM 39: 175-192.

Pauly, D. 1984. Fish population dynamics in tropical waters: a manual for use with programmable calculatrs. ICLARM Fishbyte 2: 17-19.

Pauly, D. \& F. Arreguín. 1995. Improving Shepherd's length composition analysis (SLCA) method for growth parameter estimations. NAGA ICLARM Q. 18: 31-33.

Pauly, D. \& J. Caddy. 1985. A modification of Bhattacharya's method for the analysis of mixtures of normal distributions. FAO Fish. Circ. 781: 16.

Pauly, D. \& N. David. 1981. ELEFAN I. a BASIC program for the objective extraction of growth parameters from length frequency data. Meeresforsch 28: 205-211.

Pauly, D., J. Ingles \& R. Neal. 1984. Application to shrimp stocks of objective methods for the estimation of growth, mortality and recruitment-related parameters from length-frequency data (ELEFAN I and II), p. 220-234. In J. Gulland \& B. Rothschild (eds.). Penaeid shrimps, their biology and management. Fish, New Books, England.

Pauly, D. 1987. A review of the ELEFAN system for the analysis of length-frecuency data in fish \& aquatic invertebrates. ICLARM Conf. Proc. 13: 7-34.

Powell, D.G. 1979. Estimation of mortality and growth parameters from the length frequency of a catch. Rapp. P.V. Reun. CIEM 175: 167-169.

Ramírez-Luna, V., A.F. Navia \& E.A. Rubio. 2008. Food habits and feeding ecology of an estuarine fish assemblage of northern Pacific Coast of Ecuador. Pan Am. J. Aqua. Sci. 3: 361-372. 
Reyes-Bonilla, H., L.E. Calderón, O. Aburto, J.G. DíazUribe, H. Pérez-España, P. del Monte-Luna, S. LluchCota \& L. López-Lemus. 2009. La disminución del nivel trófico de las capturas pesqueras en México. Ciencia 60: 1-9.

Rodríguez-Romero, J., S. Hernández-Vázquez \& J. LópezMartínez. 2009. Desarrollo potencial de peces desaprovechados. In Diversidad Marina. Ciencia y Desarrollo. CONACYT, México. 35: 45-51.

Rodríguez-Romero, J., S. Hernández-Vázquez, LópezMartínez, D.S. Palacios, G. Ponce, J. de Anda, E. Balart, F. Galván, I. Vázquez, E de La Vega \& L.A. Abitia-Cardenas. 2008. Composición y zoogeografía de los peces demersales de la costa occidental de Baja California Sur, México. Rev. Biol. Trop. 56: 1765-1783.

Rubio, E., H. Jairo \& R. Arroyo. 2004. Crecimiento y supervivencia de dos especies de mojarras (Diapterus peruvianus y Eucinostomus currani) criadas en jaulas flotantes en la Bahía de Buenaventura (Colombia), Congreso Iberoamericano Virtual de Acuicultura. (Consultado 19 de agosto del 2005, www.civa2004. org.756-760).

Ruíz-Ramírez, S., G. Lucano-Ramírez \& J. MariscalRomero. 1997. Length-Weight relationships of softbottom demersal fishes from Jalisco and Colima states, Mexico. Naga, ICLARM Q. 20: 62-63.
Sherperd, J.G. 1987. A weakly parametric method for estimating growth parameters from length composition data, p 113-120. In D. Pauly \& G. Morgan (eds.). Length-based methods in fisheries research. ICLARM Conf. Proc. 13. Kuwait Institute for Scientific Research. Manila, Philippines.

Sparre, P. \& S.C. Venema. 1995. Introducción a la Evaluación de los Recursos Pesqueros Tropicales. Parte 1. Manual. FAO Fish. Tech. Paper 85673, Rome, Italy.

Vazzoler, A.E.A. de M. \& G.Vazzoler. 1965. Relation between condition factor and sexual development in Sardinella aurita (Cuv. \& Val. 1847). Anais Acad. Bras. Ciênc. 37: 353-359.

Velázquez-Velázquez, E., J. Navarro, S.E. DomínguezCisneros \& M.E. Vega-Cendejas. 2009. Lengthweight relationships for 24 fish species in a coastal lagoon of the Mexican South Pacific. J. Appl. Ichthyol. 25: 228-229.

Wetherall, J.A., J.J. Polovina \& S. Ralston. 1987. Estimating growth and mortality in steady-state fish stocks from length-frequency data. ICLARM Conf. Proc. 13: 53-74.

Yáñez-Arancibia, A. 1980. Taxonomía, ecología y estructura de las comunidades de peces en lagunas costeras con bocas efímeras del Pacífico de México. Publ. Esp. Cen. Cienc. Mar Limnol. U.N.A.M. 2: 1-303. 